\title{
Pyrolysis-Gas Chromatography/Mass Spectrometry Identification of Distinctive Structures Providing Humic Character to Organic Materials
}

\author{
Marta Fuentes* and Roberto Baigorri CIPAV-Roullier Group \\ Francisco J. González-Vila Instituto de Recursos Naturales y Agrobiología \\ Gustavo González-Gaitano University of Navarra \\ José M. García-Mina CIPAV-Roullier Group
}

Flash pyrolysis-gas chromatography/mass spectrometry (PyGC/MS) was used to study the structural transformations of humic fractions formed as a result of composting processes of diverse organic materials (solid wastes of wineries, solid olivemill wastes, domestic wastes, ovine manures plus straw, and mixtures of animal manures). Sodium hydroxide-extracted total humic-like extracts (THE; humic plus fulvic acids) from the composted and the initial noncomposted wastes and several reference humic and fulvic acids from soils were analyzed. These results were compared with results from previous studies using ${ }^{13} \mathrm{C}$-cross polarization magic angle spinning-nuclear magnetic resonance (NMR), UV-visible, and fluorescence emission spectroscopies. Alkylbenzenes and alkylphenols predominate in the pyrograms of the soil humic acids, whereas the fulvic acids showed higher contents of phenolic and polysaccharide-derived compounds. The pyrolysates of THE from the composted samples showed an increase in aromatic and nitrogenated structures and a decrease in polysaccharidederived compounds. The aromatic contents as determined by $\mathrm{Py}-\mathrm{GC} / \mathrm{MS}$ and ${ }^{13} \mathrm{C}-\mathrm{NMR}$ were well correlated in the reference humic substances and THE from composted materials $(r$ $=0.99$ and 0.94 , respectively; $P<0.01$ ) but not in the case of THE from noncomposted materials, probably due to an aliphatic enhancement in the pyrolysates of these samples and other secondary reactions. The content in alkylbenzenes was consistent with the variations found previously for several UVvisible and fluorescence indexes as a function of the degree of humification, suggesting their involvement in structures that are a characteristic feature of the formation and evolution of humic substances.
Copyright $\odot 2010$ by the American Society of Agronomy, Crop Science Society of America, and Soil Science Society of America. All rights reserved. No part of this periodical may be reproduced or transmitted in any form or by any means, electronic or mechanical, including photocopying, recording, or any information storage and retrieval system, without permission in writing from the publisher.

J. Environ. Qual. 39:1486-1497 (2010)

doi:10.2134/jeq2009.0180

Published online 20 May 2010.

Received 13 May 2009.

*Corresponding author (mfuentes@timacagro.es).

(c) ASA, CSSA, SSSA

5585 Guilford Rd., Madison, WI 53711 USA
$\mathrm{C}$ OMPOSTING IS A SUITABLE waste management method to reduce the amount of organic wastes that is accumulated in landfills (Mustin, 1987; Schaub and Leonard, 1996; Sharma et al., 1997; Brändli et al., 2005). Among the variety of organic wastes susceptible to composting are residues from agricultural, farming, and forestry activities (e.g., crop debris, residues from pruning, wood or sawdust, and cattle manures); sewage sludge or urban solid wastes; and industrial residues (e.g., wastes from olive oil processing, wineries, and paper mill wastes). The use of these composts in soils has been reported to increase soil fertility and crop production (Marchesini et al., 1988; Allievi et al., 1993; Abbasi et al., 2002), to enhance the availability of phosphorus and potassium (Giusquiani et al., 1988; Marchesini et al., 1988; Allievi et al., 1993; Weber et al., 2007), to improve soil structural stability and porosity (Gallardo-Lara and Nogales, 1987; Pagliai and Antisari, 1993; Bronick and Lal, 2005; Weber et al., 2007), and to reduce pests and diseases (Abbasi et al., 2002; Litterick et al., 2004).

Compost quality is defined in terms of stability (i.e., resistance to rapid degradation of the organic matter present in the compost) and maturity (i.e., the lack of phytotoxicity on plant growth); both are related to the degree of humification of the compost (Senesi and Plaza, 2007) and are dependent on the nature of the initial organic substrates, the time of composting, the temperature, and the oxidative conditions during composting that influence microbial activities (Mustin, 1987). Composting processes involve the transformation of the initial fresh and labile organic matter into more stable, humic-like substances. Although composting has been described as an accelerated version of the decomposition processes naturally occurring in the soil (Ait Baddi et al.,

M. Fuentes, R. Baigorri, and J.M. García-Mina, CIPAV-Roullier Group, Polígono Arazuri-Orcoyen, Calle C, No. 32, 31160, Orcoyen, Spain; F.J. González-Vila, Instituto de Recursos Naturales y Agrobiología, CSIC, P.O. Box 1052, 41080 Seville, Spain; G. González-Gaitano, Dep. Chemistry and Soil Sciences, Univ. of Navarra, 31080, Pamplona, Spain. Assigned to Associate Editor Robert Cook.
Abbreviations: AHA, a commercial humic acid from Aldrich Chemicals; ALK, alkanes/ alkenes series; COMP, group of total humic extract obtained from composted materials; HAR, heteroaromatic compounds; HS, group of humic substances with high degree of humification; LG, lignin-derived pyrolytic products; LIP, lipid derivatives; N, N-containing products; NON-COMP, group of THE obtained from the initial mixtures of fresh, noncomposted organic materials; PAH, polycyclic aromatic hydrocarbons; PCA, principal component analysis; PS, products originated in the pyrolysis of polysaccharides; Py-GC/ MS, pyrolysis-gas chromatography/mass spectrometry; SSB, spinning side bands; THE, total humic extract; ${ }^{13} \mathrm{C}-\mathrm{NMR},{ }^{13} \mathrm{C}$ nuclear magnetic resonance. 
2004), humic substances formed in soils and sediments are the result of intense organo-mineral interactions during years or centuries that cannot take place in the compost pile. Therefore, because humic substances are the main fraction of soil organic matter responsible for the agrobiological and physicochemical effects that contribute to soil fertility (Stevenson, 1994), the chemical and physicochemical characterization of the humiclike substances formed as the result of the composting processes is needed to compare their properties with the molecular, structural, and functional features of humic substances with long residence time formed in soils.

Due to the difficulty of studying these ill-defined macromolecular fractions with heterogeneous chemical composition, the combined use of different analytic techniques is recommended. Carbon-to-nitrogen ratios, soluble organic carbon concentration in water extracts, or the humic-to-fulvic acid ratio can be used as a first estimation of the organic matter transformation during composting (Senesi and Plaza, 2007). Nondegradative methods, such as fluorescence, UV-visible and infrared spectroscopies, and nuclear magnetic resonance (NMR) spectroscopy, are useful in evaluating the degree of humification of humic substances extracted from organic materials of diverse origin (Korshin et al., 1997; Ait Baddi et al., 2004; Fuentes et al., 2006). Degradative methods, such as analytical pyrolysis, may provide structural information through the division of the humic substances into smaller fragments (Bracewell et al., 1989; Stevenson, 1994). Among the different pyrolytic assessments, flash pyrolysis coupled with gas chromatography/mass spectrometry (Py-GC/MS), tetramethylammonium hydroxide-induced thermochemolysis Py-GC/MS, or pyrolysis-field ionization-mass spectrometry, are the most commonly used in the study of humic substances (Leinweber and Schulten, 1999; González-Vila et al., 2001). Analytical Py-GC/MS has been proposed as a reproducible technique that allows the characterization and differentiation of humic matter from various origins, including composted materials (Schulten and Gleixner, 1999; Dorado et al., 2003; Dignac et al., 2005; Arias et al., 2006). However, the results should be analyzed bearing in mind that pyrolysis of the sample is not complete; that some compounds, especially polar compounds, cannot be observed in the pyrolysates of the samples; and that during pyrolysis some secondary rearrangements can take place (Saiz-Jiménez, 1994a).

In this context, flash Py-GC/MS has been applied on total humic extracts (containing humic and fulvic fractions) from different composted materials and from their corresponding fresh materials, as well as International Humic Substances Society standard and reference humic and fulvic acids, to evaluate the main changes in the chemical composition as the result of the composting processes. This study might allow us to assess the similarities and differences between the pyrolytic behavior of humic substances with long residence time formed in soils and the humic-like substances formed as the result of composting of organic materials.

These results have been compared with those obtained in previous studies for the same batch of samples, in which they were analyzed by means of nondestructive techniques (UV-visible, fluorescence, and ${ }^{13} \mathrm{C}$ nuclear magnetic resonance $\left[{ }^{13} \mathrm{C}-\mathrm{NMR}\right]$ spectroscopies). This complementary study has been done with two goals: (i) to evaluate if results from pyrol- ysis analysis and ${ }^{13} \mathrm{C}-\mathrm{NMR}$ showed any relationship and (ii) to study if there were any connections between the structures identified by Py-GC/MS and spectroscopic indexes indicative of the degree of maturity (in humic-like samples) or humification (in humic substances from soils).

\section{Materials and Methods}

\section{Organic Materials}

The organic systems studied were divided into three groups: (i) humic substances (humic and fulvic acids) with diverse origin, including International Humic Substances Society standards; (ii) organic substances contained in alkaline extracts obtained from composted materials; and (iii) organic substances contained in alkaline extracts obtained from the initial mixture of organic materials used in the different composting procedures.

Soil humic acids from different origins were used in this study: a humic acid extracted from a North-Bohemia (NorthWest of the Czech Republic) young coal (oxyhumolite), named CZHA; a commercial humic acid from Aldrich Chemicals (Milwaukee, WI) (AHA); a Leonardite standard humic acid; and a Pahokee peat reference humic acid; a Suwannee River reference fulvic acid (SRFA); and a Waskish peat reference fulvic acid (WRFA) (the two latter humic acids and the two fulvic acids used in this study were purchased from the International Humic Substances Society, Denver, CO).

Total humic extracts were obtained from the following noncomposted and composted (C) raw materials: solid olive-mill wastes (OLV, OLVC), solid wastes of wineries (GW, GWC); domestic wastes (DW, DWC), ovine manures plus straw (STW, OVC), and a mixture of animal manures (FM, FMC). The starting materials were piled in rows, and these piles were periodically turned over to aerate and homogenize the mixtures. The piles were turned six times over the 4-mo composting period.

All the samples studied in this work are the same as those characterized by different spectroscopic techniques and chemical methods described in previous papers (Fuentes et al., 2006, 2007).

\section{Extraction Procedure}

The different organic systems were extracted from solid samples of the organic materials (without any previous lipid extraction with organic solvents) with $0.1 \mathrm{~mol} \mathrm{~L}^{-1} \mathrm{NaOH}(24$ $\mathrm{h}$ of mechanical shaking in darkness) at $22^{\circ} \mathrm{C}$. The air was displaced by $\mathrm{N}_{2}$ in the extraction process. The sample/extractant ratio used was 1:6 for all samples but was 1:10 for straw (straw needed a larger volume of $\mathrm{NaOH}$ solution because of its great liquid absorption capacity). The suspension was centrifuged at $11,100 \times g$ for $15 \mathrm{~min}$, and the alkaline supernatants were treated with an acidic-cation exchange resin (Amberlite IR120H; Rohm and Haas Co., Philadelphia, PA) to lower the $\mathrm{pH}$ to 3.5 before freeze-drying.

\section{Pyrolysis-Gas Chromatography/Mass Spectrometry}

The flash pyrolysis experiments were performed with a PY2020iD pyrolyzer (Frontier Laboratories Ltd., Fukushima, Japan) directly attached to a GC/MS. The pyrolysis was performed by heating approximately 0.5 -mg samples to $500^{\circ} \mathrm{C}$ 
for $1 \mathrm{~min}$. This temperature was chosen because it has been reported to be a good compromise for heterogeneous materials containing polysaccharides, proteins, and lignins (SaizJiménez, 1994a, 1994b) and because it has been used previously in the study of humic substances extracted from composts (González-Vila et al., 1999), soil, and aquatic humic substances (MacCarthy et al., 1985; Schulten and Gleixner, 1999; González-Vila et al., 2001) and composts (Franke et al., 2007; González-Vila et al., 2009). The released pyrolysates were analyzed on a GC/MS system, composed of a gas chromatograph (model 6890; Agilent, Santa Clara, CA) $(30 \mathrm{~m} \times 250 \mu \mathrm{m}$ i.d. $\times 0.25 \mu \mathrm{m}$ film thickness DB5 capillary column; helium as a

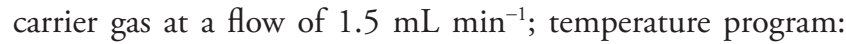
$50-100^{\circ} \mathrm{C}$ at $30^{\circ} \mathrm{C} \mathrm{min}^{-1}, 100-300^{\circ} \mathrm{C}$ at $10^{\circ} \mathrm{C} \mathrm{min}^{-1}$; injector and transfer line temperatures: 250 and $280^{\circ} \mathrm{C}$, respectively) and a mass selective detector (model 5973; Agilent) with electron ionization at $70 \mathrm{eV}$. Pyrolysis compounds were identified on the basis of their mass spectra, GC retention times, and comparison with library mass spectra. The peaks of the total ion chromatogram were integrated to obtain their area. The area of each individual peak was divided by the total area of the integrated total ion chromatogram and is expressed as a percentage of the total area.

\section{${ }^{13} \mathrm{C}$ Nuclear Magnetic Resonance Spectroscopy}

All the reference humic and fulvic acids, as well as the total humic extracts from composted and noncomposted materials, had been previously characterized by ${ }^{13} \mathrm{C}-\mathrm{NMR}$ spectroscopy (Fuentes et al., 2007). In the present work, the ${ }^{13} \mathrm{C}-\mathrm{NMR}$ data have been taken into account to study the possible correlations between the data obtained from Py-GC/MS (degradative technique) and ${ }^{13} \mathrm{C}-\mathrm{NMR}$ (nondegradative technique). ${ }^{13} \mathrm{C}$ nuclear magnetic resonance spectra were obtained using the cross-polarization magic angle spinning technique on a Varian Unity spectrometer (Varian Inc., Palo Alto, CA) operating at $75.429 \mathrm{MHz}$ with a spinning speed of $5 \mathrm{kHz}, 90^{\circ}$ pulse width, $1 \mathrm{~ms}$ contact time, $69 \mathrm{~ms}$ acquisition time, and $1.0 \mathrm{~s}$ delay (for further information and percentages of ${ }^{13} \mathrm{C}$ distribution, see Fuentes et al., 2007).

The technique of ${ }^{13} \mathrm{C}$ CPMAS NMR spectra of humic substances is not fully quantitative. Contact time (i.e., the time required to obtain the cross polarization between proton and carbon nuclei) is a critical parameter in acquisition of the spectra because aromatic carbons need longer contact time than aliphatic carbons to achieve an efficient cross polarization (Fawcett et al., 1990; Sihombing et al., 1996). Notwithstanding this fact, it has been reported that $1 \mathrm{~ms}$ of contact time is usually a good compromise between the enhancement of aliphatic and aromatic $\mathrm{C}$ signals when recording ${ }^{13} \mathrm{C}-\mathrm{NMR}$ spectra of humic substances (Fawcett et al., 1990; Peuravuori et al., 2003), and this value is commonly used in ${ }^{13} \mathrm{C}$-NMR studies of humic substances (e.g., Fabbri et al., 1998; González-Vila et al., 2001). Another factor that contributes to the inaccuracy of NMR data is the occurrence of spinning side bands (SSB), which reduce the intensity of the central band, especially in $\mathrm{sp}^{2}$-hybridized carbons (Peuravuori et al., 2003). This can be overcome by using sideband suppression pulse sequences or by recording the spectra at higher spinning rates. The spectra and results considered in this study were obtained without suppression of SSB; therefore, these results must be considered as semiquantitative, although some studies comparing quantification of ${ }^{13} \mathrm{C}$ CPMAS NMR spectra of humic substances recorded with or without total suppression of SSB at the same conditions as ours have shown that, although suppression of SSB is advisable, the error was not as great as expected (Fawcett et al., 1990; Peuravuori et al., 2003), mainly when integration is performed dividing the spectra into relative wide regions and not based on the quantification of specific peaks.

\section{Statistical Analysis}

Principal component analysis (PCA) was performed using the SPSS software version 12.0 (SPSS Inc., Chicago, IL).

\section{Results and Discussion}

\section{Pyrolysis-Gas Chromatography/ Mass Spectrometry Study}

The main products identified in the pyrolysates of the different samples are listed in Table 1. To facilitate intersample comparisons, the compounds identified in the pyrolysates were grouped into several classes: products originated in the pyrolysis of polysaccharides (PS), N-containing compounds (N), lignin-derived products (LG), polycyclic aromatic hydrocarbons (PAH), heteroaromatic compounds (HAR), lipid derivatives (LIP: fatty acids, fatty acid methyl esters, amides and cholesterol derivatives), and alkanes/alkenes series (ALK). The percentages obtained in the different samples are presented in Table 2. Total aromatic content has been calculated as the sum of AR, LG, and HAR.

Regarding the possible origin of the compounds found in the pyrolysates, cyclopentene structures (e.g., cyclopentenones and alkylated derivatives) and furan-derived compounds (e.g., furanmethanol or furancarboxaldehyde) are known pyrolysis products of polysaccharides (Saiz-Jiménez et al., 1979). The group of N-containing compounds comprises derivatives of pyrrole, pyrimidine, benzonitrile, or indole. Compounds based in pyridine structures are indicative of alanine-containing proteins (Bracewell and Robertson, 1984; Chiavari and Galletti, 1992; Basiuk and Douda, 2000). Pyrrole derivatives are originated from proteins containing glycine, proline, hydroxyproline, or glutamic amino acids (Boon and de Leeuw, 1987; Basiuk and Douda, 2000). Pyrroles can also be originated in the pyrolysis of chlorophyll pigments, although the pyrrole derivatives found in the pyrolysates of our samples did not show the typical distribution of pyrrole units that is found in the pyrolysates of chlorophyll (Sinninghe-Damsté et al., 1992). Indole-derived compounds are the result of the pyrolysis of tryptophan-containing proteins (Tsuge and Matsubara, 1985), whereas benzonitriles and benzenepropanenitrile are released in the pyrolysis of phenylalanine-containing peptides (Tsuge and Matsubara, 1985).

No specific origin can be attributed to phenolic compounds, except for guaiacol and syringol derivatives, which have been reported to be pyrolysis products of lignin (Faix et al., 1987). Phenol, $C_{1}-C_{3}$ alkylphenols, and other phenolic derivatives found in lower proportions and not mentioned in Table 1 can be released in the pyrolysis of proteins, polycar- 
Table 1. Main products found in the pyrolysates of humic acids, fulvic acids, and total humic-like extracts from composted and noncomposted samples.

\begin{tabular}{|c|c|c|c|}
\hline \multicolumn{2}{|c|}{$\mathrm{N}$-containing compounds } & \multicolumn{2}{|c|}{ Polysaccharide-derived compounds } \\
\hline$\overline{\mathrm{N} 1}$ & pyrrole & $\overline{P S 1}$ & methylfuran \\
\hline N2 & pyridine & PS2 & $\mathrm{C}_{2}$-alkylfuran \\
\hline N3 & 2-methylpyrimidine & PS3 & acetylfuran \\
\hline N4 & methyl- $1 \mathrm{H}$-pyrrole & PS4 & furanylethanone \\
\hline N5 & pyridinamine & PS5 & $\mathrm{C}_{3}$-alkylfuran \\
\hline N6 & methylpyridine & PS6 & 2-furancarboxaldehyde \\
\hline N7 & $\mathrm{C}_{2}$-alkylacetamide & PS7 & cyclopentenone \\
\hline N8 & $\mathrm{C}_{2}$-alkylpyrrole & PS8 & 2-furanmethanol \\
\hline N9 & $\mathrm{N}$-acetylpyridine & PS9 & cyclopentenedione \\
\hline N10 & $\mathrm{C}_{2}$-alkylpyridine & PS10 & methylcyclopentenone \\
\hline N11 & methoxypyridine & PS11 & $2(5 H)$-furanone \\
\hline $\mathrm{N} 12$ & formylpyrrole & PS12 & methyl-2(5H)-furanone \\
\hline N13 & benzonitrile & PS13 & methylfurancarboxaldehyde \\
\hline N14 & methylbenzonitrile & PS14 & benzofuran \\
\hline N15 & $\mathrm{C}_{3}$-alkylpyrrole & PS15 & $\mathrm{C}_{2}$-alkylcyclopentenone \\
\hline N16 & pyridinecarbonitrile & PS16 & hydroxymethylcyclopentenone \\
\hline N17 & $\mathrm{C}_{4}$-alkylpyrrole & PS17 & methylcyclopentenedione \\
\hline N18 & $\mathrm{C}_{3}$-alkylpyridine & PS18 & methylbenzofuran \\
\hline N19 & dimethylpyrimidinone & PS19 & ethylhydroxycyclopentenone \\
\hline $\mathrm{N} 20$ & aminophenol & PS20 & $\mathrm{C}_{2}$-alkylbenzofuran \\
\hline $\mathrm{N} 21$ & $\mathrm{~N}$-acetylpyrrolidine & PS21 & dibenzofuran \\
\hline $\mathrm{N} 22$ & 2-phenylacetonitrile & PS22 & furocoumarin \\
\hline $\mathrm{N} 23$ & acetamidofuran & & \\
\hline N24 & piperidinone & \multicolumn{2}{|c|}{ Aromatic compounds with unspecific origin } \\
\hline N25 & benzenepropanenitrile & AR1 & benzene \\
\hline N26 & quinoline & AR2 & toluene \\
\hline N27 & quinazoline & AR3 & $\mathrm{C}_{2}$-alkylbenzene \\
\hline N28 & indanone & AR4 & styrene \\
\hline N29 & $1 H$-indole & AR5 & $\mathrm{C}_{3}$-alkylbenzene \\
\hline N30 & methylindole & AR6 & benzaldehyde \\
\hline N31 & $\mathrm{N}$-pyridinylacetamide & AR7 & phenol \\
\hline N32 & $\mathrm{N}$-aminophenylacetamide & AR8 & $\mathrm{C}_{4}$-alkylbenzene \\
\hline & & AR9 & hydroxybenzaldehyde \\
\hline \multicolumn{2}{|c|}{ Compounds derived from lignin } & AR10 & cresol (methylphenol) \\
\hline LG1 & acetophenone & AR11 & $\mathrm{C}_{2}$-alkylphenol \\
\hline LG2 & guaiacol & AR12 & $\mathrm{C}_{3}$-alkylphenol \\
\hline LG3 & methylguaiacol & AR13 & naphthalene \\
\hline LG4 & ethylguaiacol & AR14 & biphenyl \\
\hline LG5 & vinylguaiacol & AR15 & methylnaphthalene \\
\hline LG6 & syringol & AR16 & $\mathrm{C}_{2}$-alkylnaphthalene \\
\hline LG7 & propylguaiacol & AR17 & $\mathrm{C}_{3}$-alkylnaphthalene \\
\hline LG8 & propenylguaiacol & AR18 & $\mathrm{C}_{4}$-alkylnaphthalene \\
\hline LG9 & vanillin & AR19 & phenoxyphenol \\
\hline LG10 & acetovanillone & AR20 & phenanthrene \\
\hline LG11 & ethylsyringol & AR21 & methylphenanthrene \\
\hline LG12 & homovanillyn & AR22 & $\mathrm{C}_{2}$-alkylphenanthrene \\
\hline LG13 & homovanillyl alcohol & AR23 & $\mathrm{C}_{3}$-alkylphenanthrene \\
\hline LG14 & propenylsyringol & AR24 & $\mathrm{C}_{4}$-alkylphenanthrene \\
\hline LG15 & acetosyringone & AR25 & benzothiazole \\
\hline LG16 & vinylphenol & & \\
\hline
\end{tabular}

boxylic acids, lignin, or carbohydrates (Bracewell et al., 1980; Tsuge and Matsubara, 1985; Almendros et al., 1997), so they have been included in the group of aromatic compounds of unspecific origin, as well as substituted benzenes and phenols. Polycyclic aromatic hydrocarbons, such as naphthalene, phen- anthrene, fluorene, and their alkylated derivatives, also appeared in the pyrolysates of the samples. These compounds have no specific origin; they may have an anthropogenic origin, or they may be the result of the cracking of the humic core or the consequence of the cyclization of unsaturated fatty acids or other aliphatic chains (Saiz-Jiménez, 1995; Almendros et al., 1997; Göbbels and Püttmann, 1997).

The main pyrolysis products yielded by soil humic acids are aromatic compounds of unspecific origin, as well as aliphatic chains ( $n$-alkane/ $n$-alkene doublets) (Fig. 1; Table 2). $n$-Alkanes and $n$-alkenes $\left(\mathrm{C}_{10}-\mathrm{C}_{32}\right)$ are easily identifiable in HS pyrograms, with no predominance of even or odd carbon number, whereas in the pyrograms of THE from composted and noncomposted samples, the length of the chains is shorter (up to $\mathrm{C}_{22}$ ), its area with respect to the total program is much lower, and there is a predominance of even-length chains. The origin of these series of alkyl compounds is not clear. Alkyl chains with high carbon number $\left(\mathrm{C}_{21}-\right.$ $\mathrm{C}_{33}$ ) are indicative of plant waxes, usually with an oddover-even predominance, whereas shorter chains may originate from microbial biopolymers (Sohn, 1986; Tegelaar et al., 1989; Lichtfouse et al., 1998). Several studies suggest that the existence of aliphatic domains in humic substances could be explained by the selective preservation during humification of highly aliphatic biopolymers and their subsequent integration into the humic fraction, with no even-over-odd predominance (Almendros et al., 1996, 2000; Lichtfouse et al., 1998). However, because there was no previous lipid extraction with organic solvents, under the alkaline conditions of the extraction of humic substances, lipids present in the raw samples may have saponificated and may have been coextracted within the total-humic extract, and the coexistence of products derived from thermal breakdown and thermoevaporation in the pyrograms makes it impossible to determine the source of the $n$-alkane $/ n$-alkene series in the samples studied here. The AHA showed a predominant aliphatic pattern, where $n$-alkane/ $n$-alkene doublets account for $40 \%$ of the total area under the program (Table 2) and alkylbenzenes account for $13.8 \%$. Other researchers have previously stated that this commercial humic acid from Aldrich had a very high aliphatic content (Malcolm, 1986; Shin et al., 1999; Fuentes et al., 2007).

Alkylbenzenes series, considered typical fragments of humic acids (Leinweber and Schulten, 1999), are present in the pyrograms of the other soil humic acids as well as PAH and differently substituted phenols. The high abundance of aromatic pyrolytic products (66.6-71.8\%, with the exception of AHA) could be indicative of the relatively high degree of humification of these samples. Total humic extract from composted samples showed higher content in aromatic compounds than the corresponding THE from noncomposted materials (Table 2), and the same trend was observed for alkylbenzenes and alkylphenols, which could be an indicator of the evolution, transformation, and stabilization of the organic 
Table 2. Relative abundances of the main pyrolysis products groups (percentages of the total pyrogram area).

\begin{tabular}{|c|c|c|c|c|c|c|c|c|c|c|c|c|}
\hline \multirow[b]{2}{*}{ Families } & \multirow{2}{*}{$\begin{array}{c}\text { Organic } \\
\text { substancest }\end{array}$} & \multicolumn{11}{|c|}{ Compounds $\neq$} \\
\hline & & PS & $\mathrm{N}$ & LG & AR & LIP & ALK & HAR & PAH & TAR & $\begin{array}{c}\text { Alkyl- } \\
\text { benzenes }\end{array}$ & $\begin{array}{c}\text { Alkyl- } \\
\text { phenols }\end{array}$ \\
\hline \multirow{2}{*}{$\begin{array}{l}\text { Domestic } \\
\text { wastes }\end{array}$} & DW & 23.7 & 2.9 & 7.8 & 33.0 & 0.0 & 2.4 & 13.0 & 15.1 & 53.8 & 7.0 & 9.7 \\
\hline & DWC & 11.0 & 21.9 & 7.1 & 18.6 & 0.0 & 0.2 & 27.9 & 1.3 & 53.6 & 6.4 & 8.1 \\
\hline \multirow{2}{*}{$\begin{array}{l}\text { Grape } \\
\text { wastes }\end{array}$} & GW & 22.6 & 7.4 & 12.6 & 21.9 & 3.6 & 1.3 & 10.4 & 3.7 & 44.9 & 7.3 & 10.8 \\
\hline & GWC & 6.9 & 17.6 & 5.2 & 29.4 & 0.0 & 0.0 & 24.7 & 2.9 & 59.3 & 8.3 & 14.1 \\
\hline \multirow{2}{*}{$\begin{array}{l}\text { Olive } \\
\text { wastes }\end{array}$} & OLV & 13.4 & 4.4 & 4.4 & 8.0 & 29.7 & 2.4 & 14.9 & 2.4 & 27.3 & 0.5 & 3.6 \\
\hline & OLVC & 16.1 & 14.1 & 8.0 & 21.1 & 0.4 & 0.0 & 26.2 & 2.4 & 55.3 & 3.8 & 13.6 \\
\hline \multirow{2}{*}{$\begin{array}{l}\text { Ovine } \\
\text { manure }\end{array}$} & STW & 10.0 & 0.9 & 34.1 & 19.5 & 1.8 & 0.7 & 1.7 & 2.4 & 55.3 & 1.2 & 15.9 \\
\hline & OVC & 5.0 & 13.1 & 21.4 & 25.4 & 0.1 & 0.2 & 22.7 & 0.1 & 69.6 & 4.6 & 16.0 \\
\hline \multirow{2}{*}{$\begin{array}{l}\text { Animal } \\
\text { manure }\end{array}$} & FM & 0.0 & 57.2 & 1.4 & 11.2 & 10.9 & 0.2 & 13.9 & 0.6 & 27.1 & 1.4 & 1.5 \\
\hline & FMC & 4.0 & 27.8 & 6.0 & 14.2 & 1.7 & 1.3 & 29.3 & 0.0 & 49.5 & 4.1 & 7.2 \\
\hline \multirow[t]{2}{*}{ HS§ } & $\mathrm{AHA}$ & 1.7 & 0.3 & 0.8 & 23.9 & 0.0 & 40.0 & 1.3 & 7.1 & 26.0 & 13.8 & 3.0 \\
\hline & $\mathrm{CZHA}$ & 4.8 & 3.9 & 0.0 & 63.5 & 0.4 & 11.4 & 8.3 & 7.1 & 71.8 & 36.4 & 15.5 \\
\hline \multirow[t]{4}{*}{ HS-IHSSף } & LSHA & 4.4 & 0.6 & 3.4 & 61.9 & 0.0 & 12.5 & 3.1 & 10.4 & 68.4 & 27.6 & 16.5 \\
\hline & PRHA & 5.6 & 12.4 & 8.3 & 43.3 & 0.0 & 2.1 & 15.0 & 17.8 & 66.6 & 18.2 & 14.6 \\
\hline & SRFA & 25.1 & 2.4 & 1.8 & 34.5 & 0.0 & 0.0 & 20.7 & 4.4 & 57.0 & 6.7 & 15.9 \\
\hline & WRFA & 31.7 & 1.1 & 5.9 & 35.6 & 0.0 & 0.0 & 31.0 & 11.4 & 72.5 & 7.2 & 26.7 \\
\hline
\end{tabular}

+ CZHA, humic acid extracted from a North-Bohemia (North-West of the Czech Republic) young coal (oxyhumolite); DW, domestic wastes; DWC, composted domestic wastes; FM, mixed animal manures; FMC, composted mixed animal manures; GW, solid wastes of wineries; GWC, composted solid wastes of wineries; LSHA, Leonardite standard humic acid; OLV, olive-mill wastes; OLVC, composted olive-mill wastes; OVC, composted ovine manures plus straw; PRHA, Pahokee peat reference humic acid; SRFA, Suwannee River reference fulvic acid; STW, ovine manures plus straw; WRFA, Waskish peat reference fulvic acid.

₹ AHA, humic acid from Aldrich Chemicals; ALK, alkanes/alkenes; AR, aromatic compounds with unspecific origin; HAR, heteroaromatic compounds; LG, compounds derived from lignin; LIP, lipid compounds; N, nitrogen-containing compounds; PAH, polycyclic aromatic hydrocarbons; PS, compounds derived from polysaccharides; TAR, total aromatic content.

$\S \mathrm{HS}$, humic substances with high degree of humification.

I HS-IHSS, humic substances from the International Humic Substances Society.

matter as a result of the composting processes. A higher content in PAH (especially in soil humic acids) might also indicate a higher condensation degree of the aromatic structures. Some studies have reported that PAHs are formed in cyclization reactions of aliphatic moieties during pyrolysis (Saiz-Jiménez, 1995), although certain conditions must occur. For example, lipid chain cyclization occurs in the presence of elemental sulfur (Saiz-Jiménez, 1994a, 1995); on the other hand, condensation of fatty acids is favored in the presence of catalysts such as oxides or clays (Almendros, 2008), and molecules entrapped into microporous matrices undergo cyclization more easily that volatile alkyl chains readily released by thermoevaporation. Apart from secondary reactions, PAHs can also be released during the pyrolysis of lignin (Sharma and Hajaligol, 2003) or plant steroids (Britt et al., 2001), although PAHs are typically released from pyrolysis of fossil organic matter (Almendros et al., 1998). Lignin derivatives were found in low quantities in the reference HS studied. Although it has been reported that the abundance of guaiacol and its derivatives is favored by lower temperatures (e.g., $510^{\circ} \mathrm{C}$ compared with $600^{\circ} \mathrm{C}$ ) (Sihombing et al., 1996), several studies have remarked that lignin derivatives can be underestimated without the use of tetramethylammonium hydroxide-induced thermochemolysis (del Río et al., 2007).

Fulvic acids (SRFA and WRFA) also show a high aromatic content (about 35\%) (Table 2) that mainly consists of differently substituted phenols, besides polysaccharide derivatives, chiefly cyclopentenes and furans, which account for 25 to $32 \%$ of the pyrolysates of these samples. Although a decrease in
PS-derived structures is expected with an increase of humification, as decomposition proceeds, microorganisms might produce new secondary or carbohydrate-like products, and this could be one reason for the enrichment in PS-type compounds in fulvic acids (Stevenson, 1994). Relative high content in polysaccharides has also been found previously for FA from different origins (Sihombing et al., 1996; Cook and Langford, 1998; Schulten and Gleixner, 1999). Fulvic acids also show pyrograms that are less complex than those of humic acids or THE from composted and noncomposted samples (Fig. 1 and 2). A main feature of fulvic acids is their high content in carboxylic groups (Stevenson, 1994), but as decarboxylation occurs during pyrolysis, those compounds cannot be detected in the pyrolysates without the protection of the carboxylic groups by a chemical agent (e.g., tetramethylammonium hydroxide). Thus, the content in oxidized lignin structures and in other acidic entities is underestimated in these pyrolysates. It is possible that some of the phenols detected in the pyrogram of fulvic acids have undergone decarboxylation during the pyrolysis, as occurs with coumaric acids (del Río et al., 2007).

Regarding THE from composted materials, the products identified by pyrolysis show that the humic-like fractions of composts undergo an enrichment in aromatic structures in the course of the composting process when they are compared with THE from noncomposted organic materials (Table 2). The content in heteroaromatic compounds, mainly in N-containing compounds (positively correlated $[r=0.94$; $P<0.01]$ to nitrogen percentages determined by elemental analysis [Fuentes et al., 2007]), increases in THE from 

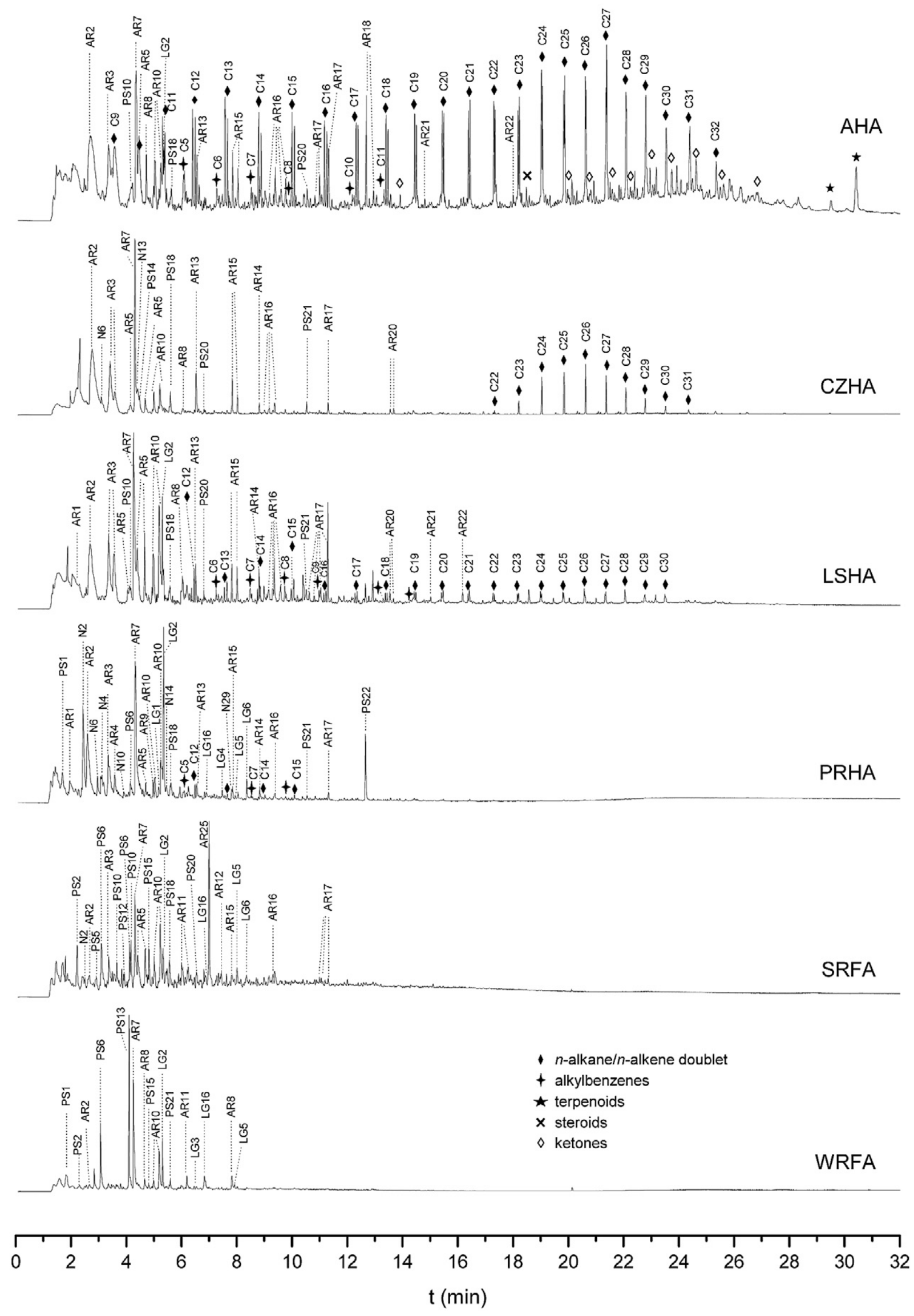

Fig. 1. Pyrograms of humic and fulvic acids from soils and humic substances from the International Humic Substances Society. Compounds corresponding to each label are listed in Table 1. AHA, humic acid from Aldrich Chemicals; CZHA, a humic acid extracted from a North-Bohemia (North-West of the Czech Republic) young coal (oxyhumolite); LSHA, Leonardite standard humic acid; PRHA, Pahokee peat reference humic acid; SRFA, Suwannee River reference fulvic acid; WRFA, Waskish peat reference fulvic acid. 


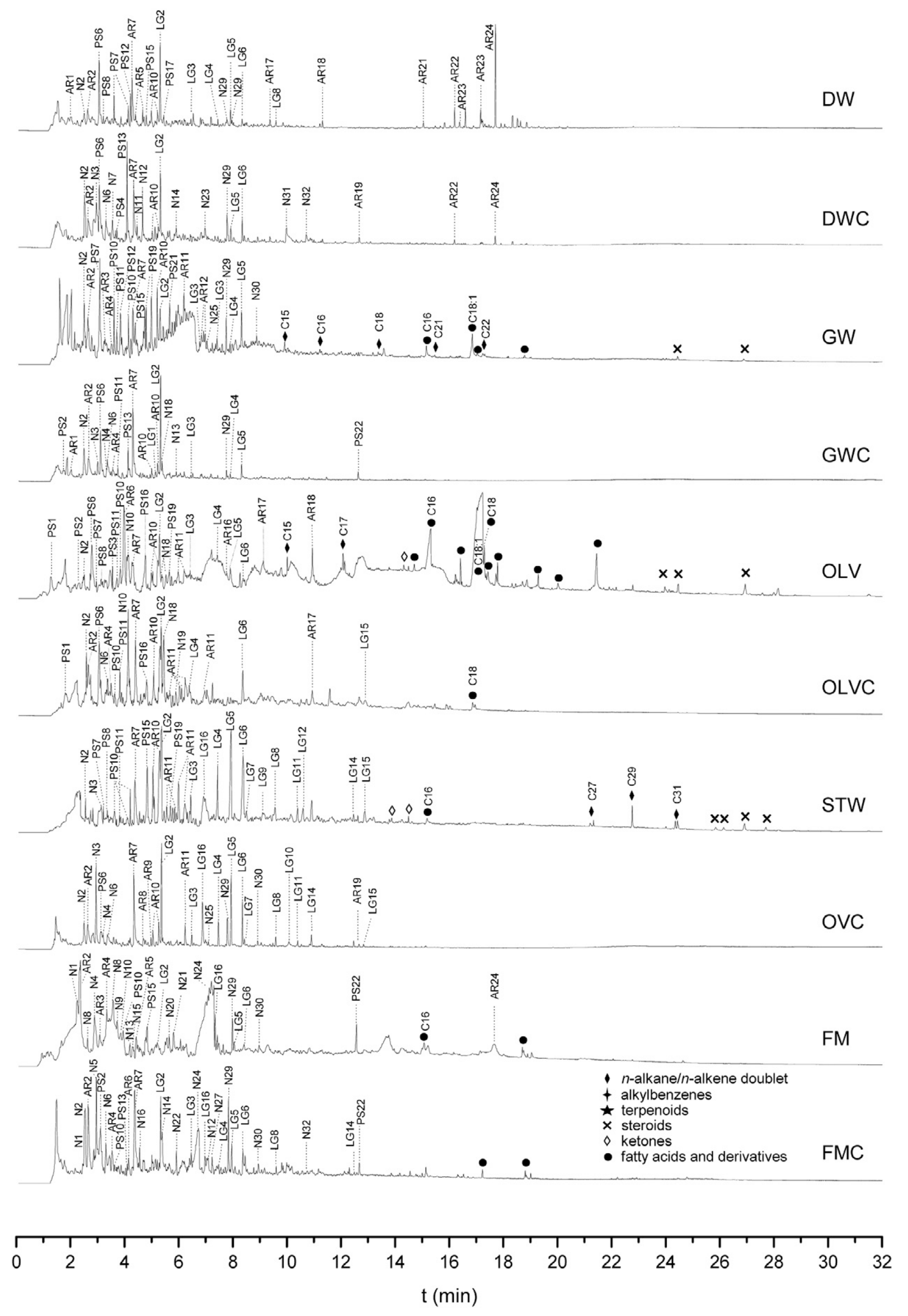

Fig. 2. Pyrograms of total humic-like extracts from noncomposted and composted samples. Compounds corresponding to each label are listed in Table 1. 
composted materials. This can be the combined result of an increment in aromatic structures and the incorporation of nitrogen into the humified portion of the composted samples (Veeken et al., 2000). In the pyrograms of humic and fulvic acids, only relatively low amounts of $\mathrm{N}$-containing products have been identified, which suggests that, apart from considering that THE contain humic and fulvic fractions, based on pyrolysis results further transformations in THE in composted samples are needed to achieve similar structural assemblages to those showed by the humic substances with long residence times formed in soils and sediments.

The results from pyrolysis analysis regarding aromatic structures are in line with previous spectroscopic studies for THE in which several UV-visible and fluorescence indexes were associated with the degree of humification of the samples (Fuentes et al., 2006). In that study, increments of the spectroscopic indexes were observed as a result of the composting processes, which were attributed to an increase in the aromatic content of THE from composted materials or to the presence of more condensed or conjugated structures, whereas humic substances with long residence time formed in soils, sediments, and water presented higher values of these indexes.

\section{Principal Component Analysis}

The areas of the peaks with the same core structures were added and expressed as percentages of total area (data not shown). Principal component analysis was performed based on the correlation matrix of this data set, extracting principal components with eigenvalues higher than 1. Principal component analysis can better illustrate the similarities and differences between samples. Thus, samples with similar chemical composition (or at least similar proportions of families of compounds found in the pyrolysates) show close PCA scores and are represented as a cluster in the PCA score plot. On the other hand, higher heterogeneity between the samples results in more scattered points in the PCA score plot. The first 10 PCs with eigenvalues higher than 1 describe $90 \%$ of the total vari(B) factor scores.
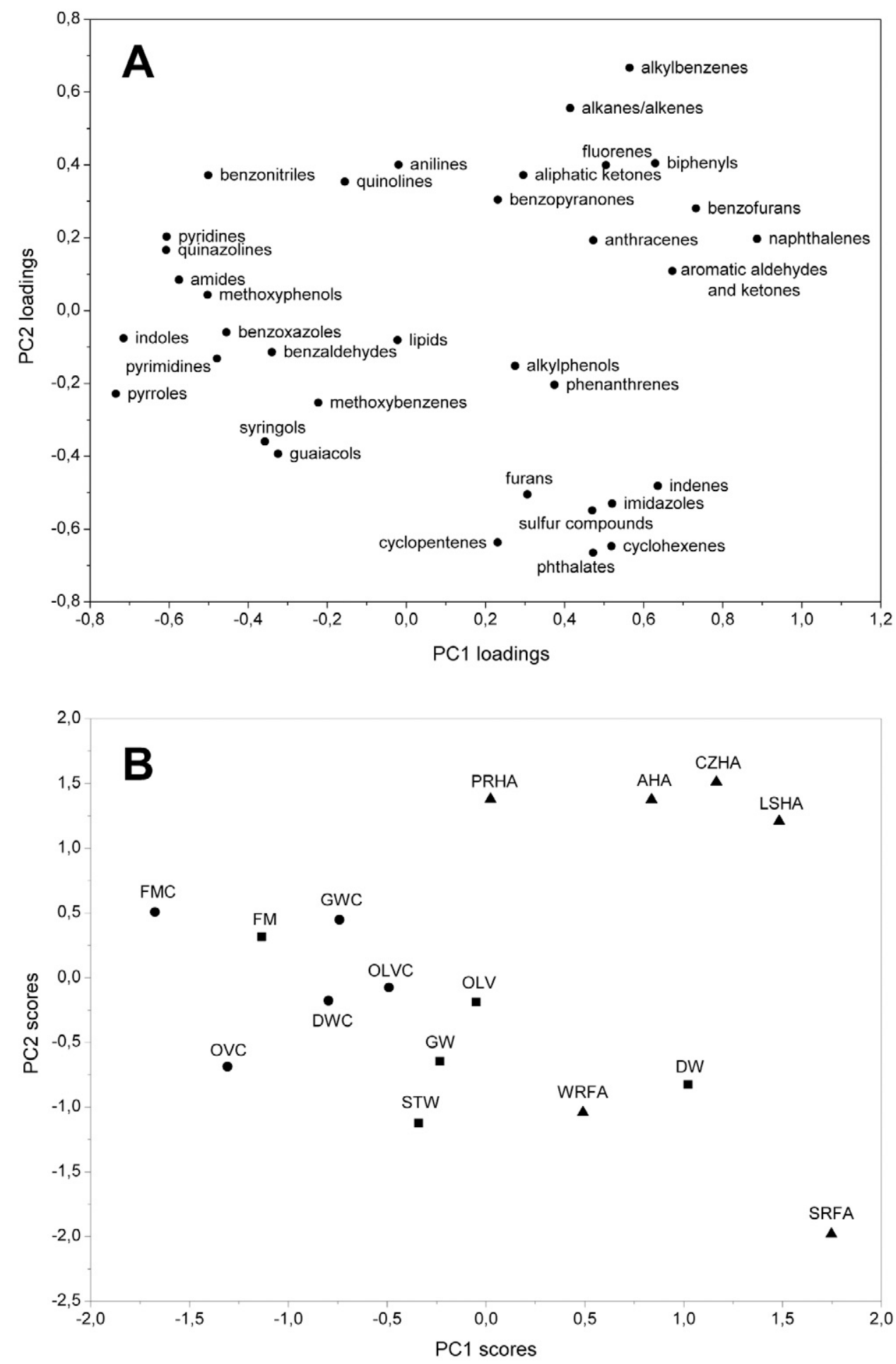

Fig. 3. Principal component analysis based on pyrolysis-gas chromatography/mass spectrometry data. Representation in the plane defined by the two first principals (PC1 and PC2) of (A) factor loadings and

ance. The first principal component (PC1) explained $24 \%$ of the total variance, and the second component (PC2) explained $14 \%$ of the total variance. Although the total variance explained by these two components is not very high, these components are useful to associate the main structures found in the pyrolysates with the samples. The variables with higher contribution in $\mathrm{PC} 1$ are naphthalenes, $\mathrm{N}$-containing compounds (pyrroles, indoles, and pyridines), benzofurans, aromatic aldehydes, and 
ketones. On the other hand, PC2 is described mainly by alkylbenzenes, alkanes/alkenes, PS-derived compounds (cyclohexenes and cyclopentenes), imidazoles, and sulfur compounds.

Three clusters are distinguished in Fig. 3b: One includes the humic acids, one includes the fulvic acids, and one includes THE from composted and noncomposted materials. Within the third cluster, the trend to an internal separation of composted and noncomposted samples can be observed. The loading plot is a representation of the correlation between the variables and the components. The cluster of soil humic acids has high positive scores in PC1 and PC2, components positively correlated mainly to aromatic structures, such as alkylbenzenes, aromatic aldehydes and ketones, benzofurans, and several PAHs. The second cluster has positive scores in PC1 and negative scores in PC2, indicating that the main descriptors of these samples are the PS-derived compounds, as well as phthalates and sulfur compounds, but also with those aromatic structures positively correlated with PC1. The main structures that described the third cluster are those negatively correlated to $\mathrm{PC1}$, predominantly $\mathrm{N}$-heteroaromatic compounds (pyridines, pyrimidines, and pyrroles) and oxygenated structures such as benzoxazoles, benzaldehydes, and methoxyphenols (different from guaiacols or syringols).

\section{Comparison with Spectroscopic Data}

Data from Py-GC/MS have been considered together with ${ }^{13} \mathrm{C}-\mathrm{NMR}$ data reported in a previous study for this same batch of samples (for percentages of ${ }^{13} \mathrm{C}$ distributions, see Fuentes et al., 2007). Due to the different nature of the studied samples, data from Py-GC/MS and ${ }^{13} \mathrm{C}-\mathrm{NMR}$ were studied considering three groups individually to avoid possible masking of correlations: (i) humic substances with a high degree of humification (HS), (ii) THE from fresh organic materials (NON-COMP), and (iii) THE from composted materials (COMP). Thus, correlations between the ${ }^{13} \mathrm{C}-\mathrm{NMR}$ and Py-GC/MS data sets were conducted over each group (Table 3). No significant correlations were found in the case of the NON-COMP group; therefore, those data are not shown in Table 3.

The fact that AR content in the NON-COMP group did not show any correlation with aromatic $\mathrm{C}$ estimated by ${ }^{13} \mathrm{C}$ NMR suggests that these aromatic products found in their pyrolysates probably resulted from the pyrolysis of proteins or other aliphatic compounds. In THE belonging to the NONCOMP group (and also possibly in the rest of the samples), aromatic $\mathrm{C}$ percentages determined by ${ }^{13} \mathrm{C}-\mathrm{NMR}$ probably account not only for aromatic carbons but also for a considerable amount of unsaturated structures (especially in the case of THE from olive mill wastes); hence the lack of correlation between ${ }^{13} \mathrm{C}-\mathrm{NMR}$ and $\mathrm{Py}-\mathrm{GC} / \mathrm{MS}$ results with respect to aromatic structures. These extracts from NON-COMP group are aliphatic in character as determined by ${ }^{13} \mathrm{C}-\mathrm{NMR}$ (Fuentes et al., 2007), and the use of a nonpolar column for GC separation of the pyrolysis products leads to an enhancement of aliphatic components at the expense of the more polar compounds

Table 3. Pearson correlation coefficients (linear fit) between pyrolysis-gas chromatography/mass spectrometry and ${ }^{13} \mathrm{C}$ nuclear magnetic resonance datat from composted samples (COMP group) and humic substances with high degrees of humification (HS group).

\begin{tabular}{|c|c|c|c|c|c|}
\hline & Alkyl C & O-alkyl C & Aromatic C & Phenolic C & Carbonylic C \\
\hline & \multicolumn{5}{|c|}{ COMP group } \\
\hline PS $\neq$ & -0.14 & 0.51 & 0.13 & -0.03 & -0.69 \\
\hline$N$ & $0.95^{*}$ & 0.08 & -0.79 & -0.85 & -0.01 \\
\hline LG & -0.69 & 0.11 & 0.25 & 0.50 & 0.12 \\
\hline AR & -0.83 & -0.62 & $0.99^{* *}$ & $0.97^{* *}$ & 0.41 \\
\hline LIP & 0.78 & -0.02 & -0.82 & -0.73 & 0.29 \\
\hline ALK & 0.80 & 0.01 & -0.85 & -0.75 & 0.26 \\
\hline HAR & $0.97^{*}$ & 0.38 & -0.85 & $-0.96^{* *}$ & -0.35 \\
\hline PAHs & -0.26 & -0.31 & 0.63 & 0.40 & -0.06 \\
\hline Alkylbenzenes & -0.36 & -0.56 & 0.67 & 0.57 & 0.30 \\
\hline \multirow[t]{3}{*}{ Alkylphenols } & $-0.95^{*}$ & -0.39 & 0.83 & $0.94^{*}$ & 0.37 \\
\hline & \multicolumn{5}{|c|}{ HS group } \\
\hline & Alkyl C & O-alkyl C & Aromatic C & Phenolic C & Carbonylic C \\
\hline PS & -0.33 & -0.33 & -0.34 & -0.33 & 0.81 \\
\hline$N$ & -0.48 & -0.66 & 0.26 & 0.42 & 0.37 \\
\hline LG & -0.58 & -0.62 & 0.19 & 0.37 & 0.56 \\
\hline AR & -0.59 & -0.42 & $0.94^{* *}$ & $0.84^{*}$ & -0.31 \\
\hline LIP & -0.15 & -0.23 & 0.48 & 0.41 & -0.31 \\
\hline ALK & $0.91^{*}$ & $0.87^{*}$ & -0.32 & -0.34 & $-0.82^{*}$ \\
\hline HAR & -0.52 & -0.60 & -0.19 & -0.11 & $0.91^{*}$ \\
\hline PAHs & -0.17 & -0.28 & 0.20 & 0.41 & 0.02 \\
\hline Alkylbenzenes & -0.27 & -0.24 & $0.82^{*}$ & 0.78 & -0.56 \\
\hline Alkylphenols & $-0.81^{*}$ & -0.73 & 0.38 & 0.4 & 0.63 \\
\hline
\end{tabular}

* Significant at $P<0.05$.

** Significant at $P<0.01$.

$+{ }^{13} \mathrm{C}$ nuclear magnetic resonance data (not shown here) have been taken from a previous study (Fuentes et al., 2007).

‡ ALK, Alkanes/alkenes; AR, aromatic compounds with unspecific origin; HAR, heteroaromatic compounds; LG, compounds derived from lignin; LIP, lipid compounds; N, N-containing compounds; PAHs, polycyclic aromatic hydrocarbons; PS, compounds derived from polysaccharides. 
(Dignac et al., 2006), a phenomenon that can be extended to the whole set of samples.

The content in aromatic compounds identified in the pyrograms of the HS and COMP groups is in agreement with aromatic and phenolic carbon percentages determined by ${ }^{13} \mathrm{C}-\mathrm{NMR}$ (Table 3). Other studies have found the same trend (González-Vila et al., 2001; Baigorri et al., 2009), although aromatic hydrocarbons can be thermal degradation products of many types of structures.

In the case of HS group, aromatic C content estimated by ${ }^{13} \mathrm{C}-\mathrm{NMR}$ is positively correlated with alkylbenzene content $(r$ $=0.82 ; P<0.05)$ and showed no correlation with alkylphenol content. In the case of the COMP group, the correlation of the percentage of aromatic $\mathrm{C}$ was stronger with alkylphenol content $(r=0.83$, although not significant at $P<0.05)$, and the percentage of phenolic $\mathrm{C}$ and alkylphenol contents were positively correlated $(r=0.94 ; P<0.05)$. This discrepancy could be partially explained because aromatic $\mathrm{C}$ accounts for all the types of aromatic hydrocarbons as well as unsaturated $\mathrm{C}$ (the same is true for phenolic $\mathrm{C}$ and alkylphenols) and by the inaccuracy derived from both techniques.

No correlation was expected regarding carbonylic carbon content because pyrolysis entails the loss of carboxylic groups. However, and only in the case of the HS group, carbonylic carbon shows a significant positive correlation with the content in heteroaromatic compounds identified in the pyrolysates; this might be the consequence of the presence of carbonylic rather than carboxylic structures in these humic samples or the result of a spurious correlation.

Alkyl chains also showed positive correlations with aliphatic C by ${ }^{13} \mathrm{C}-\mathrm{NMR}$ (Table 3), although these correlations were significant only for HS the group (similar relationships were found by Baigorri et al. [2009] for different humic and fulvic fractions from soils), which suggests that in the COMP group, and mainly in the NON-COMP group, the structures responsible for alkyl $\mathrm{C}$ might undergo further reactions during pyrolysis and that trends but not straightforward relationships can be established between the data obtained by the two techniques.

Despite the correlations found in this study, the compounds and structures identified in the Py-GC/MS study are only a part of the sample because the pyrolysis of the sample is not complete, which is an inherent limitation of the technique and of humic samples, and because their attributed origin may not be such because the high temperatures may involve secondary reactions. Thus, the relations found with ${ }^{13} \mathrm{C}-\mathrm{NMR}$ results are only partial and are dependent on the nature of the source of the humic or humic-like extracts.

In a previous study (Fuentes et al., 2006), we observed that several indexes obtained by UV-visible and fluorescence spectroscopies were able to reflect the increase in the degree of humification of the samples, although it could only be a qualitative estimation. For the HS and COMP groups, only alkylbenzenes showed a strong, positive, and significant correlation with these spectroscopic indexes (Table 4). Although the alkylbenzenes found in the pyrolysates cannot be associated with specific structures of origin, they seem to be a reflection of the humification degree and could be representative of the more humified structures that are formed during composting and humification. Thus, a greater content in alkylbenzenes seems to be associated with a higher degree of humification. Sutton and Sposito (2005) reviewed various studies that used different techniques to characterize structural features in humic substances, the results being consistent with the presence of complex alkylaromatic acidic structures differently substituted by hydroxyl and carboxyl groups (Sutton and Sposito, 2005 and references therein).

\section{Conclusions}

The results obtained by Py-GC/MS revealed differences in the structural composition of organic matter with several degrees of humification and subjected to different composting processes. Although the pyrolyzed fractions are not fully representative of the whole humic or humic-like samples, aromatic content determined in the pyrograms of THE from composts and the reference HS agree with the aromatic carbon percentages calculated from ${ }^{13} \mathrm{C}-\mathrm{NMR}$ spectra integration.

From the Py-GC/MS results and the PCA, the following general trends can be inferred:

1. Pyrolysates of fulvic acids are composed mainly of aromatic and polysaccharide-derived compounds, whereas humic acids show higher contents in alkylbenzenes and alkylphenols.

2. In general, the composting process leads to the decomposition of polysaccharide structures, the formation of aromatic structures, and the incorporation of $\mathrm{N}$-containing compounds, reflected in the pyrolysates as a higher content in N-heteroaromatic compounds.

3. Pyrograms of THE from composted materials show a

Table 4. Pearson correlation coefficients between the content in alkylbenzenes, determined by pyrolysis-gas chromatography/mass spectrometry and several ultraviolet-visible and fluorescence indexes indicators of the degree of humification of the samples.

\begin{tabular}{|c|c|c|}
\hline Indext & Description & Alkylbenzenes \\
\hline$\varepsilon_{60}$ & molar absorptivity at $600 \mathrm{~nm}\left(\mathrm{~g} \mathrm{C}^{-1} \mathrm{~L} \mathrm{~cm}^{-1}\right)$ in $0.1 \mathrm{~mol} \mathrm{~L}^{-1} \mathrm{NaOH}$ & $r=0.84^{* *} ; \mathrm{y}=1.99 \mathrm{x}+0.76$ \\
\hline $\mathrm{E}_{\mathrm{ET}} / \mathrm{E}_{\mathrm{BZ}}$ & ratio of absorbances at 253 and $220 \mathrm{~nm}$ in the UV spectrum (measured in $0.010 \mathrm{~mol} \mathrm{~L}^{-1}$ sodium acetate) & $r=0.76^{* *} ; y=0.012 x+0.476$ \\
\hline$\varepsilon_{280}$ & molar absorptivity at $280 \mathrm{~nm}\left(\mathrm{~g} \mathrm{C}^{-1} \mathrm{~L} \mathrm{~cm}^{-1}\right)$ in $0.010 \mathrm{~mol} \mathrm{~L}^{-1}$ sodium acetate & $r=0.88^{* *} ; \mathrm{y}=34.0 \mathrm{x}+62.4$ \\
\hline$A_{440}^{200}$ & $\begin{array}{l}\text { area under fluorescence emission spectra }\left(460-650 \mathrm{~nm} \text { ) recorded with } \lambda_{\text {exc }}=440 \mathrm{~nm}\right. \\
\left.\text { (solutions of } 10 \mathrm{mg} \mathrm{CL}^{-1} \text { in } 0.05 \mathrm{~mol} \mathrm{~L}^{-1} \mathrm{NaHCO}_{3}\right)\end{array}$ & $r=0.88^{* *} ; \mathrm{y}=335 \mathrm{x}+918$ \\
\hline $\mathrm{A}_{4} / \mathrm{A}_{1}$ & $\begin{array}{l}\text { ratio of areas of last quarter }(570-641 \mathrm{~nm} \text { ) and first quarter }(356-432 \mathrm{~nm} \text { ) of fluorescence emission } \\
\text { spectra with } \lambda_{\text {exc }}=240 \mathrm{~nm} \text { (solutions of } 10 \mathrm{mg} \mathrm{CL}^{-1} \text { in } 0.05 \mathrm{~mol} \mathrm{~L}^{-1} \mathrm{NaHCO}_{3} \text { ) }\end{array}$ & $r=0.83^{* *} ; \mathrm{y}=0.0216 \mathrm{x}-0.0873$ \\
\hline
\end{tabular}

** Significant at $P<0.01$.

† Spectroscopic indexes have been taken from a previous study (Fuentes et al., 2006). 
tendency to increase pyrolytic structures resembling those found in reference HS, indicating a stabilization of the organic matter in these fractions. Further transformations (probably only possible in soils and with the course of years) are needed to achieve chemical arrangements similar to that of humic substances naturally formed in soils and sediments.

4. The positive and significant correlation found between alkylbenzenes and several UV-visible and fluorescence indexes indicative of the degree of humification suggests that alkylbenzenes seem to be to some extent linked to structures that are characteristic features of humic substances and their degree of humification. These results support the conclusion that alkylbenzenes, besides being possible artifacts generated during the pyrolysis, could be considered as unspecific cleavage products typical of humic substances of advanced degree of maturity.

\section{References}

Abbasi, P.A., J. Al-Dahmani, F. Sahin, H.A.J. Hoitink, and S.A. Millar. 2002. Effect of compost amendments on disease severity and yield of tomato in conventional and organic production systems. Plant Dis. 86:156-161.

Ait Baddi, G., M. Hafidi, J. Cegarra, J.A. Alburquerque, J. Gonzálvez, V. Gilard, and J.-C. Revel. 2004. Characterization of fulvic acids by elemental and spectroscopic (FTIR and ${ }^{13} \mathrm{C}$ NMR) analyses during composting of olive mill wastes plus straw. Bioresour. Technol. 93:285-290.

Allievi, L., A. Marchesini, C. Salardi, V. Piano, and A. Ferrari. 1993. Plant quality and soil residual fertility six years after a compost treatment. Bioresour. Technol. 43:85-89.

Almendros, G. 2008. Humic acids. p. 315-323. In W. Chesworht (ed.) Encyclopedia of soil science. Springer, Dordrecht, the Netherlands.

Almendros, G., J. Dorado, F.J. González-Vila, M.J. Blanco, and U. Lankes. 2000. ${ }^{13} \mathrm{C}$ NMR assessment of decomposition patterns during composting of forest and shrub biomass. Soil Biol. Biochem. 32:793-804.

Almendros, G., J. Dorado, F.-J. González-Vila, and F. Martín. 1997. Pyrolysis of carbohydrate-derived macromolecules: Its potential in monitoring the carbohydrate signature of geopolymers. J. Anal. Appl. Pyrolysis 40-41:599-610.

Almendros, G., F.J. González-Vila, F. Martín, J. Sanz, and C. Álvarez-Ramis. 1998. Appraisal of pyrolytic techniques on different forms of organic matter from a Cretaceous Basement in Central Spain. Org. Geochem. 28:613-623.

Almendros, G., M.E. Guadalix, F.J. González-Vila, and F. Martín. 1996. Preservation of aliphatic macromolecules in soil humin. Org. Geochem. 24:651-659.

Arias, M.E., O. Polvillo, J. Rodríguez, M. Hernández, J.A. González-Pérez, and F.J. González-Vila. 2006. Thermal transformations of pine wood components under pyrolysis/gas chromatography/mass spectrometry conditions. J. Anal. Appl. Pyrolysis 77:63-67.

Baigorri, R., M. Fuentes, G. González-Gaitano, J.M. García-Mina, G. Almendros, and F.J. González-Vila. 2009. Complementary multianalytical approach to study the distinctive structural features of the main humic fractions in solution: Gray humic acid, brown humic acid, and fulvic acid. J. Agric. Food Chem. 57:3266-3272.

Basiuk, V.A., and J. Douda. 2000. Pyrolysis of poly-glycine and poly-L-alanine: Analysis of less-volatile products by gas chromatography/Fourier transform infrared spectroscopy/mass spectrometry. J. Anal. Appl. Pyrolysis 55:235-246.

Boon, J.J., and J. W. de Leeuw. 1987. Amino acid sequence information in proteins and complex proteinaceous material revealed by pyrolysis-capillary gas chromatography-low and high resolution mass spectrometry. J. Anal. Appl. Pyrolysis 11:313-327.

Bracewell, J.M., K. Haider, S.R. Larter, and H.-R. Schulten. 1989. Thermal degradation relevant to structural studies of humic substances. p. 181222. In M.H.B. Hayes et al. (ed.) Humic substances II: In search of structure. John Wiley \& Sons, Chichester, UK.

Bracewell, J.M., and G.W. Robertson. 1984. Quantitative comparison of the nitrogen-containing pyrolysis products and amino acid composition of soil humic acids. J. Anal. Appl. Pyrolysis 6:19-29.
Bracewell, J.M., G.W. Robertson, and D.I. Welch. 1980. Polycarboxylic acids as the origin of some pyrolysis products characteristics of soil organic matter. J. Anal. Appl. Pyrolysis 2:239-248.

Brändli, R.C., T.D. Bucheli, T. Kupper, R. Furrer, F.X. Stadelmann, and J. Tarradellas. 2005. Persistent organic pollutants in source-separated compost and its feedstock materials: A review of field studies. J. Environ. Qual. 31:735-760.

Britt, P.F., A.C. Buchanan, III, M.M. Kidder, C. Owens, J.R. Ammann, J.T. Skeen, and L. Luo. 2001. Mechanistic investigation into the formation of polycyclic hydrocarbons from the pyrolysis of plant steroids. Fuel 80:1727-1746.

Bronick, C.J., and R. Lal. 2005. Soil structure and management: A review. Geoderma 124:3-22.

Chiavari, G., and G.C. Galletti. 1992. Pyrolysis-gas chromatography/mass spectrometry of amino acids. J. Anal. Appl. Pyrolysis 24:123-137.

Cook, R.L., and C.H. Langford. 1998. Structural characterization of a fulvic acid and a humic acid using solid-state ramp-CP-MAS ${ }^{13} \mathrm{C}$ nuclear magnetic resonance. Environ. Sci. Technol. 32:719-725.

del Río, J.C., A. Gutiérrez, I.M. Rodríguez, D. Ibarra, and A.T. Martínez. 2007. Composition of non-woody plant lignins and cinnamic acids by Py-GC/MS, Py/TMAH and FT-IR. J. Anal. Appl. Pyrolysis 79:39-46.

Dignac, M.-F., S. Houot, and S. Derenne. 2006. How the polarity of the separation column may influence the characterization of compost organic matter by pyrolysis-GC/MS. J. Anal. Appl. Pyrolysis 75:128-139.

Dignac, M.-F., S. Houot, C. Francou, and S. Derenne. 2005. Pyrolytic study of compost and waste organic matter. Org. Geochem. 36:1054-1071.

Dorado, J., F.-J. González-Vila, M.C. Zancada, G. Almendros, and C. LópezFando. 2003. Pyrolytic descriptors responsive to changes in humic acid characteristics after long-term sustainable management of dryland farming systems in Central Spain. J. Anal. Appl. Pyrolysis 68-69:299-314.

Fabbri, D., M. Mongardi, L. Montanari, G.C. Galletti, G. Chiavari, and R. Scotti. 1998. Comparison between CP/MAS ${ }^{13} \mathrm{C}-\mathrm{NMR}$ and pyrolysisGC/MS in the structural characterization of humins and humic acids of soil and sediments. Fresenius' J. Anal. Chem. 362:299-306.

Faix, O., D. Meier, and I. Grobe. 1987. Studies on isolated lignins and lignins in woody materials by pyrolysis-gas chromatography-mass spectrometry and off-line pyrolysis-gas chromatography with flame ionization detection. J. Anal. Appl. Pyrolysis 11:403-416.

Fawcett, A.H., J. Grimshaw, J. Trocha-Grimshaw, F. Donnelly, and B.J. Say 1990. CP/MAS n.m.r. spectra of samples from the Ulster lignite deposits. Fuel 69:415-420.

Franke, M., G. Jandl, and P. Leinweber. 2007. Analytical pyrolysis of re-circulated leachates: Towards an improved municipal waste treatment. J. Anal. Appl. Pyrolysis 79:16-23.

Fuentes, M., R. Baigorri, G. González-Gaitano, and J.M. García-Mina. 2007. The complementary use of ${ }^{1} \mathrm{H}$ NMR, ${ }^{13} \mathrm{C}$ NMR, FTIR and size exclusion chromatography to investigate the principal structural changes associated with composting of organic materials with diverse origin. Org. Geochem. 38:2012-2023.

Fuentes, M., G. González-Gaitano, and J.M. García-Mina. 2006. The usefulness of UV-visible and fluorescence spectroscopies to study the chemical nature of humic substances from soils and composts. Org. Geochem. 37:1949-1959.

Gallardo-Lara, F., and R. Nogales. 1987. Effect of the application of town refuse compost on the soil-plant system: A review. Biol. Wastes 19:35-62.

Giusquiani, P.L., C. Marucchini, and M. Businelli. 1988. Chemical properties of soils amended with compost of urban waste. Plant Soil 109:73-78.

Göbbels, F.-J., and W. Püttmann. 1997. Structural investigation of isolated aquatic fulvic and humic acids in seepage water of waste deposits by pyrolysis-gas chromatography/mass spectrometry. Water Res. 31:1609-1618.

González-Vila, F.J., G. Almendros, and F. Madrid. 1999. Molecular alterations of organic fractions from urban waste in the course of composting and their further transformation in amended soil. Sci. Total Environ. 236:215-229.

González-Vila, F.J., J.A. González-Pérez, K. Akdi, M.D. Gómis, F. PérezBarrera, and T. Verdejo. 2009. Assessing the efficiency of urban waste biocomposting by analytical pyrolysis (Py-GC/MS). Bioresour. Technol. 100:1304-1309.

González-Vila, F.J., U. Lankes, and H.-D. Lüdemann. 2001. Comparison of the information gained by pyrolytic techniques and NMR spectroscopy on the structural features of aquatic humic substances. J. Anal. Appl. Pyrolysis 58-59:349-359.

Korshin, G.V., C.-W. Li, and M.M. Benjamin. 1997. Monitoring the properties of natural organic matter through UV spectroscopy: A consistent theory. Water Res. 31:1787-1795. 
Leinweber, P., and H.-R. Schulten. 1999. Advances in analytical pyrolysis of soil organic matter. J. Anal. Appl. Pyrolysis 49:359-383.

Lichtfouse, É., C. Chenu, F. Baudin, C. Leblond, M. Da Silva, F. Behar, S. Derenne, C. Largeau, P. Wehrung, and P. Albrecht. 1998. A novel pathway of soil organic matter formation by selective preservation of resistant straight-chain biopolymers: Chemical and isotope evidence. Org. Geochem. 28:411-415.

Litterick, A.M., L. Harrier, P. Wallace, C.A. Watson, and M. Wood. 2004. The role of uncomposted materials, compost, manures and compost extracts in reducing pest and disease incidence and severity in sustainable temperate agricultural and horticultural crop production: A review. Crit. Rev. Plant Sci. 23:453-479.

MacCarthy, P., S.J. Deluca, and K.J. Voorhees. 1985. Pyrolysis-mass spectrometry/pattern recognition on a well-characterized suite of humic samples. Geochim. Cosmochim. Acta 49:2091-2096.

Malcolm, R.L. 1986. Limitations in the use of commercial humic acids in water and soil research. Environ. Sci. Technol. 20:904-911.

Marchesini, A., L. Allievi, E. Comotti, and A. Ferrari. 1988. Long-term effects of quality-compost treatment on soil. Plant Soil 106:253-261.

Mustin, M. 1987. Le compost: Gestion de la matière organique. Éditions François Dubusc, Paris.

Pagliai, M., and L.V. Antisari. 1993. Influence of waste organic matter on soil micro- and macrostructure. Bioresour. Technol. 43:205-213.

Peuravuori, J., P. Ingman, and K. Pihlaja. 2003. Critical comments on accuracy of quantitative determination of natural humic matter by solid state ${ }^{13} \mathrm{C}$ NMR spectroscopy. Talanta 59:177-189.

Saiz-Jiménez, C. 1994a. Analytical pyrolysis of humic substances: Pitfalls, limitations, and possible solutions. Environ. Sci. Technol. 28:1773-1780.

Saiz-Jiménez, C. 1994b. Pyrolysis/methylation of soil fulvic acids: Benzenecarboxylic acids revisited. Environ. Sci. Technol. 28:197-200.

Saiz-Jiménez, C. 1995. Reactivity of the aliphatic humic moiety in analytical pyrolysis. Org. Geochem. 23:955-961.

Saiz-Jiménez, C., K. Haider, and H.L.C. Meuzelaar. 1979. Comparisons of soil organic matter and its fractions by pyrolysis mass-spectrometry. Geoderma 22:25-37.

Schaub, S.M., and J.J. Leonard. 1996. Composting: An alternative waste management option for food processing industries. Trends Food Sci. Technol. 7:263-268.

Schulten, H.-R., and G. Gleixner. 1999. Analytical pyrolysis of humic sub- stances and dissolved organic matter in aquatic systems: Structure and origin. Water Res. 33:2489-2498.

Senesi, N., and C. Plaza. 2007. Role of humification processes in recycling organic wastes of various nature and source as soil amendments. Clean Soil Air Water 35:26-41.

Sharma, V.K., M. Canditelli, F. Fortuna, and G. Cornacchia. 1997. Review Processing of urban and agro-industrial residues by aerobic composting. Energy Convers. Manage. 38:453-478.

Sharma, R.K., and M.R. Hajaligol. 2003. Effect of pyrolysis conditions on the formation of polycyclic aromatic hydrocarbons (PAHs) from polyphenolic compounds. J. Anal. Appl. Pyrolysis 66:123-144.

Shin, H.-S., J.M. Monsallier, and G.R. Choppin. 1999. Spectroscopic and chemical characterizations of molecular size fractionated humic acid. Talanta 50:641-647.

Sihombing, R., P.F. Greenwood, M.A. Wilson, and J.V. Hanna. 1996. Composition of size exclusion fractions of swamp water humic and fulvic acids as measured by solid state NMR and pyrolysis-gas chromatographymass spectrometry. Org. Geochem. 24:859-873.

Sinninghe-Damsté, J.S., T.I. Eglinton, and J.W. de Leeuw. 1992. Alkylpyrroles in a kerogen pyrolysate: Evidence for abundant tetrapyrrole pigments. Geochim. Cosmochim. Acta 56:1743-1751.

Sohn, M.L. 1986. Organic Marine geochemistry: An overview. p. 1-8. In M.L. Sohn (ed.) Organic marine geochemistry. ACS Symposium Series 305. American Chemical Society, Washington, DC.

Stevenson, F.J. 1994. Humus chemistry. John Wiley \& Sons, New York.

Sutton, R., and G. Sposito. 2005. Molecular structure in soil humic substances: The new view. Environ. Sci. Technol. 23:9009-9015.

Tegelaar, E.W., J.W. de Leeuw, and C. Sáiz-Jiménez. 1989. Possible origin of aliphatic moieties in humic substances. Sci. Total Environ. 81/82:1-17.

Tsuge, S., and H. Matsubara. 1985. High resolution pyrolysis-gas chromatography of proteins and related materials. J. Anal. Appl. Pyrolysis 8:49-64.

Veeken, A., K. Nierop, V. de Wilde, and B. Hamelers. 2000. Characterization of $\mathrm{NaOH}$-extracted humic acids during composting of a biowaste. Bioresour. Technol. 72:33-41.

Weber, J., A. Karczewska, J. Drozd, M. Licznar, S. Licznar, E. Jamroz, and A. Kocowicz. 2007. Agricultural and ecological aspects of a sandy soil as affected by the application of municipal solid waste composts. Soil Biol. Biochem. 39:1294-1302. 